\title{
Post-harvest siderates impact on the weed littering of Maize
}

\author{
O.Yu. Karpenko ${ }^{1}$, V.M. Rozhko ${ }^{1}$, A.O. Butenko ${ }^{2 *}$, I.M. Masyk ${ }^{2}$, L.V. Malynka ${ }^{3}$, I.M. Didur ${ }^{4}$, \\ I.V. Vereshchahin ${ }^{2}$, A.S. Chyrva ${ }^{2}$, S.I. Berdin ${ }^{2}$ \\ ${ }^{1}$ National University of Life and Environmental Sciences of Ukraine, Kyiv, Heroiv Oborony Str. 15, Ukraine \\ ${ }^{2}$ Sumy National Agrarian University, Sumy, H. Kondratieva Str. 160, Ukraine \\ ${ }^{3}$ State Institution "Scientific and Methodological Center of Higher and Professional Higher Education", Kyiv, Smilyanska \\ str. 11, Ukraine \\ ${ }^{4}$ Vinnytsia National Agrarian University, Vinnytsia, Soniaczna St. 3, Ukraine \\ E-mail: andb201727@ukr.net
}

Received: 23.09.2019. Accepted: 23.10.2019

\begin{abstract}
The problem of post-harvest winter rapeseed crops usage influencing siderate and green fodder, oil radish impacting siderate and forage, root and post-harvest remains of winter wheat, and also cattle manure ( $40 \mathrm{t} / \mathrm{ha})$ influencing the weed littering of maize and grain under conditions of grain-cultivated crop rotation has been revealed by PS of NUBiP of Ukraine - Agronomic research station. It has been proved that the cleanest crops of maize on the typical low-humus and light-loamy black soils remained in the variants where its predecessors were oil radish and winter rape on green fertilizer. Compared to control (root and post-harvest remains of winter wheat), weed amount decreased by 54 and $37 \%$ accordingly. Oil radish had a sufficient toxic effect on weeds as it was evidenced by their weight which in this variant decreased under shelf cultivation by $72 \%$ and under chisel cultivation - by $61 \%$. Higher yield of maize for both chisel and shelf cultivation was forming in variants with oil radish for siderate and green fodder. The yield increase was 0.3-1.0 under shelf cultivation and 0.7-1.2 t/ha under chisel cultivation.
\end{abstract}

Key words: Maize for grain; Siderate; Oil radish; Winter rapeseed; Shelf cultivation; Chisel cultivation; Weed littering

\section{Introduction}

One of significant factors influencing the production of agricultural products is weed littering of crops (Zakharenko, 1988). Weeds create substantial competition for agricultural crops in the use of life factors as most of them are well adapted to environmental conditions and their presence in agrophytocenoses causes great harm. Costs for crop protection from weeds compose about $30 \%$ of total agricultural costs (Fisiunov, 1984). An effective means of controlling weeds among agricultural crops is the use of chemicals. However, the problem of environmental pollution by herbicides forces their more careful application (Vityazev, 1991).

At present, humanity is concerned about increasing influence of anthropogenic factors on agrophytocenoses. The usage of large amount of mineral fertilizers and chemical means of plant protection leads to soil and groundwater contamination, violation of microbiological processes in the soil and, as a result, to its degradation. In this regard, at this stage has arisen a rather difficult problem of improving the soil environment and alternative measures of weed control are being searched for its solution (Vityazev, 1991; Krupa, 1995; Didur, 2019).

There exists an opinion concerning weed littering reduction of the following crop rotation crops while using intermediate winter and spring crops of cabbage family. Some scientists have found that weed littering per $1 \mathrm{~m}^{2}$ after winter rapeseed decreased to $39.9 \%$. The usage of post-harvest crops of this plant after cereals reduced weed littering by 90-96\% (Uteush, 1979; Tsyhanskyi, 2019). At the same time, post-harvest crops fill up the soil with quickly hydrolyzing organic material, normalize soil microbiological processes, improve physical properties of soil and support the rational use of moisture (Begey, 1992; Voznyakovskaya, 1988).

Thus, today the problem of search less harmful to environment measures of reducing weed amount in agricultural crop growing is deepening and encouraging further research.

\section{Materials and Methods}

The aim of the research was to study the effect of post-harvest crops on siderate and green fodder on weed littering of maize. The research took place in a stationary field crop rotation of Agronomy research station of NUBiP of Ukraine, where agro-technical, chemical, biological and complex measures of weed control are studied. These measures foresee the following alternation of crops: 1- clover; 2 - winter wheat + post-harvest crops; 3 - corn for grain; 4 - peas; 5 - winter wheat + post-harvest crops; 6- sugar beets; 7 - silage corn; 8 - winter wheat; 9 - barley with clover sowing. The soil of experimental plot - typical low humus black soil with humus content in the arable layer $-4.2-4.5 \%$, pH $-6.8-7.3$, amount of general nitrogen - $0.27-0.31$, phosphorus - $0.14-$ 0,25 , potassium $-2,3-2,5 \%$.

The scheme of the experiment provides studying of the following variants: 1) control (root and post-harvest remains of winter wheat); 2) manure, 40 t/ha; 3) winter rapeseed for siderate; 4) winter rapeseed for green fodder; 5) oil radish for siderate; 6) oil radish for feed. In the experiment with maize were used shelf and chisel measures of basic soil cultivation to a depth of $28-30 \mathrm{~cm}$. Weed littering of crops was estimated by quantitative and weighing method with determination of species composition. The quantity, species composition and mass of weeds were calculated by direct counting of plants in 5-fold repetition in the phase of maize panicle flowering and before harvesting. The allelopathic activity of the most widespread weed species by bio-testing method (Grodzinskiy, 1973; Butenko, 2019) and the content of water-soluble phenolic substances (Alexandrova, 1985) have been also determined. 


\section{Results and Discussion}

On the basis of analysis of conditions under which the experiment was conducted and observations it should be noted that the years of research conducting were favorable for the growth and development of not only cultivated plants but also for weeds when their mass in the flowering phase of maize reached $1 \mathrm{~kg}$. Made in our experiments calculations of maize crops weed littering during vegetation period show that the amount and mass of weeds depended on both basic cultivation and post-harvest crops.

Usage of shelf cultivation helped to significant clearing its crops from weeds (Table 1). Thus, in flowering phase in the control after shelf cultivation amount of weeds was $24 \mathrm{pcs} / \mathrm{m}^{2}$, and after non-shelf cultivation $-31 \mathrm{pcs} / \mathrm{m}^{2}$. Apparently, friendly germination of weed seeds and then active growth and development during chisel cultivation one may explain by the fact that significant amount of seeds remains in the top layer of soil where conditions for accumulation and storage of moisture are more favorable and therefore aeration improves. This contributes to more friendly germination and finally to an increase of maize crops weed littering.

Post-harvest crops under different forms of their usage influenced weed littering considerably. The purest maize crops remained in variants where their predecessors were oil radish and winter rapeseed for green fertilizer. In comparance with the control weeds decreased to $54 \%$ and $37 \%$ respectively. Oil radish had a sufficient toxic effect on weeds, as it was evidenced by their weight. In this case, it decreased by $72 \%$ under shelf processing and by $61 \%$ under chisel processing.

Table 1. Impact of basic soil cultivation measures and post-harvest crops on weed littering of maize (flowering phase).

\begin{tabular}{|c|c|c|c|c|c|c|c|c|}
\hline \multirow{4}{*}{ Variants of experiment } & \multirow{2}{*}{\multicolumn{2}{|c|}{$\begin{array}{l}\text { Tillage } 28-30 \mathrm{~cm} \\
\text { quantity }\end{array}$}} & \multirow[b]{2}{*}{ mass } & \multirow{4}{*}{$\begin{array}{l} \pm \quad \% \\
\text { before } \\
\text { the } \\
\text { control }\end{array}$} & \multicolumn{4}{|c|}{ Chisel cultivation $28-30 \mathrm{~cm}$} \\
\hline & & & & & \multicolumn{3}{|c|}{ quantity mass } & \multirow{3}{*}{$\begin{array}{l} \pm \quad \% \\
\text { before } \\
\text { the } \\
\text { control }\end{array}$} \\
\hline & \multirow[b]{2}{*}{$\begin{array}{l}\text { pcs/ } \\
\mathbf{m}^{2}\end{array}$} & \multirow{2}{*}{$\begin{array}{l} \pm \quad \% \\
\text { before } \\
\text { the } \\
\text { control }\end{array}$} & \multirow{2}{*}{$\mathrm{g} / \mathrm{m}$} & & & & & \\
\hline & & & & & $\begin{array}{l}\text { pcs/ } \\
\mathbf{m}^{2}\end{array}$ & $\begin{array}{l} \pm \% \text { before } \\
\text { the control }\end{array}$ & $\mathrm{g} / \mathrm{m}^{2}$ & \\
\hline The control & 24 & 0 & 917 & - & 31 & - & 1064 & - \\
\hline Manure, $40 \mathrm{t} / \mathrm{h}$ & 26 & +8 & 975 & +6 & 36 & +16 & 1123 & +5 \\
\hline $\begin{array}{l}\text { Winter rapeseed } \\
\text { siderate }\end{array}$ & 15 & -37 & 695 & -24 & 23 & -26 & 702 & -34 \\
\hline Winter rapeseed for & 12 & -35 & 762 & -21 & -19 & -22 & 783 & -29 \\
\hline Oil radish for siderate & -13 & -54 & 257 & -72 & 20 & -35 & 410 & -61 \\
\hline $\begin{array}{l}\text { Oil radish for green } \\
\text { fodder }\end{array}$ & 16 & -33 & 620 & -32 & 24 & -23 & 718 & -33 \\
\hline
\end{tabular}

It is known that among the most active allelopathic substances are phenolcarboxylic acids (ferulic, vanilic, p-oxybenzoic). Studies have shown that remains of oil radish decompose faster than others resulting in the release of mentioned allelopathically active substances. Most of them were in the variant with oil radish for siderate before sowing and in the phase of 6-7 leaves of maize (Table 2). The probable increase in ferulic, vanilic and p-oxybenzoic acids in the early stages of maize development helped to suppress weeds and reduce their amount.

As opposed to oil radish decomposition of plant tremains of winter rapeseed for siderate has reached maximum before maize harvesting. Obviously, longer period of its biomass decomposition and at the same time release of allelopathically active substances contributed to a somewhat higher weed littering of maize crops comparing with oil radish for siderate. The usage of post-harvest crops for green fodder also provided reduction of weed amount under shelf cultivation $29 \%$ with winter rapeseed, - $33 \%$ with oil radish, and 16 and $23 \%$ under chisel cultivation respectively.

Table 2. Content of phenolcarboxylic acids in the soil, $\mathrm{mg} / \mathrm{kg}$ (phase 6-7 leaves).

\begin{tabular}{|c|c|c|c|c|c|c|}
\hline $\begin{array}{l}\text { Acids } \\
\text { Variant of experiment } \\
\text { Ploughing } 28-30 \mathrm{~cm}\end{array}$ & Ferulic & $\begin{array}{l}\text { P- } \\
\text { coumaric }\end{array}$ & Ferulic & Vanilic & $\begin{array}{l}\text { P- } \\
\text { oxybenzoic }\end{array}$ & $\begin{array}{l}\text { O- } \\
\text { coumaric }\end{array}$ \\
\hline Control & - & 4,80 & 3,81 & 3,93 & 2,14 & 2,77 \\
\hline Manure, 40 t/ha & 1,36 & 5,22 & 3,81 & 2,50 & 2,14 & 3,20 \\
\hline Winter rapeseed for siderate & 1,90 & 4,90 & 4,08 & 3,39 & 2,25 & 3,84 \\
\hline Winter rapeseed for green fodder & 1,09 & 5,22 & 4,90 & 3,39 & 2,35 & 4,26 \\
\hline Oil radish for siderate & 1,36 & 4,80 & 6,81 & 4,11 & 2,78 & 4,48 \\
\hline Oil radish for green fodder & 1,36 & 5,97 & 4,63 & 3,93 & 2,35 & 2,98 \\
\hline Chisel cultivation $28-30 \mathrm{~cm}$ deep & & & & & & \\
\hline $\begin{array}{l}\text { Control (root and stubble remains of } \\
\text { winter wheat) }\end{array}$ & 1,63 & 5,76 & 5,72 & 4,11 & 2,99 & 3,20 \\
\hline Manure, $40 \mathrm{t} / \mathrm{ha}$ & 1,90 & 6,40 & 6,26 & 4,47 & 2,61 & 4,48 \\
\hline Winter rapeseed for siderate & 2,18 & 6,82 & 6,81 & 4,65 & 2,42 & 5,97 \\
\hline Winter rapeseed for green fodder & 1,66 & 6,61 & 6,53 & 4,11 & 2,99 & 5,33 \\
\hline Oil radish for siderate & - & 5,76 & 4,08 & 4,65 & 2,35 & 5,12 \\
\hline Oil radish for green fodder & 1,36 & 5,12 & 3,81 & 3,57 & 1,92 & 4,26 \\
\hline
\end{tabular}

Observations and calculations showed that in agrocenosis of maize the following types of weed were most frequently encountered: cleaver (Galium aparine), chicken millet (Echinochloa crиs-galli), common amaranth (Amaranthus rertroflexus), white orach 
(Chenopodium aIbum) and pink sow-thistle (Cirsium arvense). Most of them did not reach reproductive phase of development. Sideration helped to reduce amount of chicken millet and white orach. But in the variant with the usage of oil radish amount of cleaver increased.

Allelopathic weed activity was studied in our observations. It was found out that cleaver was distinguished to be more active than chicken millet and white orach. Root increase of watercress compared to the control was $42.2 \%$, for chicken millet - $51.5 \%$ and for white orach-53.5\%. Obtained results are coordinated with the data of other literature which prove that allelopathic activity is caused by phenolic compositions which are part of root secretions or which are formed during the destruction of vegetative mass (Grodzinskiy, 1982; Rice, 1987; Kolisnyk, 2019).

The content of water-soluble phenolic compositions in the plant mass of cleaver was the highest (1040 mkg/g). It may be assumed that cleaver is positively influenced by plant mass of oil radish and its high allelopathic potential allows to occupy a dominant position in agrocenosis.

Thus, post-harvest crops affect the state of maize weed littering. Under favorable conditions for the period of sowing and sprouts appearance of oil radish and winter rapeseed grown after harvest increases germination of weed seeds that ultimately helps to reduce potential weed littering of maize.

Soil cultivation measures similar to post-harvest crops had an impact on maize productivity (Table 3). Higher grain yield for both chisel and shelf cultivation was formed in variants with oil radish for siderate and green fodder. The yield increase was $0.3-1.0$ under shelf cultivation and 0.7-1.2 t/ha under chisel cultivation.

Table 3. Impact of post-harvest crops and measures of basic soil cultivation on the yield of maize, $\mathrm{t} / \mathrm{ha}$.

\section{Soil cultivation}

\section{Variants of experiment}

Control

Manure, 40 t/ha

Winter rapeseed for siderate

Winter rapeseed for green fodder

Oil radish for siderate

Oil radish for green fodder

SSD05 factor A - soil cultivation - 0,10 t/ha;

factor B- post-harvest crops $-0,16 \mathrm{t} / \mathrm{ha}$.

\section{ploughing 28-30 cm.}

7,1

8,1

7,4

7,0

8,1

7,9

\section{Chisel cultivation $\mathbf{2 8 - 3 0} \mathrm{cm}$.}

$$
\begin{aligned}
& 7,0 \\
& 7,9 \\
& 7,7 \\
& 7,5 \\
& 8,2 \\
& 8,0
\end{aligned}
$$

\section{Conclusion}

Root stubble remains and green mass of post-harvest crops of oil radish and winter rapeseed have a positive effect not only on soil processes but also on amount and species composition of weeds in agrocenosis. There is a decrease in weed littering of maize crops. All this raise some interest in the study of chemical interaction of plants in crops and the impact of their decomposition products as a means of controlling weeds with a distinct allelopathic potential as it is evidenced in our research.

\section{References}

Alexandrova, L. P., Osipova, V.N. (1985). Methods of fractionation of phenolic compositions of conifer tissues. Research of metabolism of woody plants. Novosibirsk: Science, Sib. department. 92-102.

Begey, S. V. (1992). Intermediate crops in intensive agriculture. Svit, 160.

Vityazev, V. G., Makarov, I. B. (1991). Field littering plants. General agriculture. Moscow State University Publishing House. 201248.

Voznyakovskaya, Yu. M., Popova, Zh. P., Petrova, L. G. (1988). Sidereal fertilizers regulators of soil microbiological processes in the conditions of soil weariness. Rep. All-Union Academy of Agricultural Sciences named after Lenin, 2: 6-9.

Grodzinskiy, A. M. (1973). Fundamentals of chemical interaction of plants. K. Naukova dumka, 204.

Grodzinskiy, A. M. (1982). Study and research prospects of allelopathy in crop production. The role of allelopathy in crop production. Collection of scientific papers. Naukova dumka. 3-12.

Grodzinskiy, A. M. (1990). The sanitary role of cruciferous crops in crop rotation. Allelopathy and plant productivity. Collection of scientific papers. 8-14.

Zakharenko, V. A. (1988). Economic evaluation of weed control means. Weed control in crop production. Collection of scientific papers -M.: Agropromizdat. 22-27.

Krupa, L. I., Ilchenko, N. A., Figurovskaya, A. A. (1995). Influence of siderates on biochemical condition of soil under winter wheat. Some reserves for increase of grain production in Ukraine: Collection of scientific papers.

Rice, E. K., Urozhai, (1987). Mironovka institute of wheat named after V. N. Remeslo of UAAS, 165-170.

Allelopathy, M. Mir., Uteush, Yu. A. (1979). Rape and cole-seed in feed production - K. Naukova dumka, 228.

Fisiunov, A. V. (1984). Weed plants. -M.: Kolos, 204.

Tsyhanskyi, V. I., Didur, I. M., Tsyhanska, O. I., Malynka, L. V., Butenko, A. O., Masik, I. M., Klochkova, T. I. (2019). Effect of the cultivation technology elements on the activation of plant microbe symbiosis and the nitrogen transformation processes in alfalfa agrocoenoses. 2227-9555 e-ISSN 2226-3063 ISSN Modern Phytomorphology. 13: 30-34.

Kolisnyk, O. M., Butenko, A. O., Malynka, L. V., Masik, I. M., Onychko, V. I., Onychko, T. O., Kriuchko, L. V., Kobzhev, O. M. (2019). Adaptive properties of maize forms for improvement in the ecological status of fields. Ukrainian Journal of Ecology. 9 (2): $33-37$.

Didur, I. M., Tsyhanskyi, V. I., Tsyhanska, O. I., Malynka, L. V., Butenko, A. O., Klochkova, T. I. (2019). The effect of fertilizer system on soybean productivity in the conditions of right bank forest-steppe. Ukrainian Journal of Ecology. 9 (1): 76-80.

Butenko, A. O., Sobko, M. G., Ilchenko, V. O., Radchenko, M. V., Hlupak, Z. I., Danylchenko, L. M., Tykhonova, O. M. (2019). Agrobiological and ecological bases of productivity increase and genetic potential implementation of new buckwheat cultivars in the conditions of the Northeastern Forest-Steppe of Ukraine. Ukrainian Journal of Ecology. 9 (1): 162-168. 


\section{Citation:}

Karpenko, O.Yu., Rozhko, V.M., Butenko, A.O., Masyk, I.M., Malynka, L.V., Didur, I.M., Vereshchahin, I.V., Chyrva, A.S., Berdin, S.I. (2019). PostHarvest Siderates Impact on the Weed Littering of Maize. Ukrainian Journal of Ecology, 9(3), 300-303.

This work is licensed under a Creative Commons Attribution 4.0. License 